\title{
ACUTE TOXICITY TEST AND HISTOLOGICAL DESCRIPTION OF ORGANS AFTER GIVING NANO HERBAL ANDALIMAN (Zanthoxylum acanthopodium)
}

\author{
Putri C. Situmorang ${ }^{1}$, Syafruddin Ilyas ${ }^{1, *}$, Salomo Hutahaean ${ }^{1}$, Rosidah $^{2}$ \\ and Risma D. Manurung ${ }^{1}$ \\ ${ }^{1}$ Department of Biology, Faculty of Mathematic and Natural Sciences, Universitas Sumatera \\ Utara, Medan-20155, (Sumut) Indonesia \\ 2 Department of Pharmacy, Faculty of Pharmacy, Universitas Sumatera Utara, \\ Medan-20155, (Sumut) Indonesia \\ *E-mail: syafruddin6@usu.ac.id
}

\begin{abstract}
Andaliman is a typical plant (Northen Sumatera, Indonesia) contains antioxidants and as herbal medicine in the future. This aimed in this research to determine the toxic value of nano herbal and aliman and analyze histology of the liver, lungs, heart and brain after given of this herb. Nano herbal andaliman were made using High Energy Milling (HEM). LC50 was used Brine Shrimp Lethality Test with concentrations of 10, 100, 1000, 10000 ppm while LD50 consists of 3 stages: dose orientation test (12 mice), preliminary test (20 mice) and LD50 determination (30 mice) for 14 today by the Thomson Weil formula, then the organ was investigated for histology. The results of this research: $\mathrm{LC} 50$ value $=1737.80 \mathrm{ppm}, \mathrm{LD} 50=9.807 \mathrm{~g} / \mathrm{KgBW} \pm 0.075$ and a significant difference was noticed $(\mathrm{p}$ $<0.05)$ in liver weight but no significant difference $(\mathrm{p}>0.05)$ on the weight of lungs, heart and brain. A significant difference also in organ histology on the administration nano herbal andaliman in each dose level. Nano herbal andaliman belongs to the category of mild toxic so that it could be processed as a herbal medicine of the future.

Keywords: Acute Toxicity, Andaliman, Brine Shrimp Lethality, LD50, Nanoherbal
\end{abstract}

(C) RASĀYAN. All rights reserved

\section{INTRODUCTION}

Herbal medicines have thousands of constituents simultaneously against disease. ${ }^{1}$ Incorporation of herbal extracts into the new formulation system has problems such as dosage and lack of absorption which attract the attention of pharmaceutical companies. The increasing of herbal medicines because they have fewer side effects compared to synthetic drugs. ${ }^{2}$ Herbal plants in smaller sizes have the advantage of high loading capacity, improved surfaces and are given in high concentrations. ${ }^{3}$ Difficulty penetrating active substances on the lipid membrane of body cells is often a problem in drugs. ${ }^{4}$

Andaliman extracts contain coumarin and alkaloids (typical ingredients of the family Zanthoxylum) and steroids in considerable amounts. Andaliman also contains terpenoids as anti-fungi, antimicrobial activity and antioxidant. ${ }^{5-7}$ Zanthoxylum family contains hepatoprotective, antibiotic antiproliferative, and also as antiplasmodial, cytotoxic, anticonvulsant, and analgesic. ${ }^{8-12}$ Although nano herbal have opportunities in the treatment of various diseases but its safety is still questionable. ${ }^{13}$ Changes in the physicochemical and structural properties of nano-sized materials engineered, decreases in size are responsible for several material interactions could toxicological effects. ${ }^{14}$ Therefore a toxicity test was needed on nano herbal andaliman for an effective dose.

\section{EXPERIMENTAL}

\section{Materials}

Andaliman was obtained from traditional markets in Medan. Mice were obtained from animal cages in the Biology Laboratory, Faculty of Mathematics and Science, University of Sumatera Utara, Artemia Viper Eggs (Jeannie Hoo., LTD, China). Flakon, artemia hatchery (local), micropipette (Socorex ISBA S.A), 5- 
RASĀYAN J. Chem.

Vol. 13 | No. 2 |780 - 788| April - June | 2020

watt lamps (dop), aerator (Niko $\mathrm{Nk} 1200$ ), $0.9 \% \mathrm{NaCl}$ from Otsuka ${ }^{\circledR}$, drop pipette, analytical balance (Mettler Toledo AB204), Vortex (Dijkstra), 1 set of surgical instruments (PT. Glorya Medica Abadi), formalin and hematoxylin-eosin stains (PT. Arjuna Utama Kimia), paraffin (PT. Kirana Mitra Abadi), ethanol (Bratachem $\left.{ }^{\circledR}\right)$, xylene (PT. Anugrah Putra Kencana) and Mayer's albumin (PT. Indo Achitama Chemical Industry).

\section{Nano Herbal Andaliman}

Nano herbal andaliman has been made using the High Energy Milling ( $\mathrm{HCl} 2 \mathrm{M}$, Tokyo Japan) at the Indonesian research institute (LIPI, Jakarta). The procedure for change of herbal andaliman to be nanosize were balls as a crushing medium into a larger diameter jar then small balls and samples. HEM was turned on for 2 hours. ${ }^{15}$ The method and results of this study have been registered with a simple patent (S00201900840).

\section{Lethality Test 50 (LC50)}

LC50 used the Brine Shrimp Lethality Test. Artemia larvae into $5 \mathrm{~mL}$ vial bottles containing 10, 100, $1000,10000 \mathrm{ppm}$ nano herbal andaliman then observed for 24 hours motility and probit values.

\section{Lethal Dose 50 (LD50)}

LD50 used mice (Mus musculus) around 18-20g BW. Experimental animals were from Biology animal cages in the University of Sumatera Utara. LD50 used 3 stages; the dose orientation test (12 Mus musculus) for 24 hours; the preliminary test (20 Mus musculus) for 24 hours, ${ }^{16}$ and the determination of LD50 (30 Mus musculus) where 25 mice for treatment and 5 mice as control during 14 days. ${ }^{17}$ In the final stage, the death motility and LD50 values were calculated by the Thomson Weil formula. Histological description of the liver, kidneys, lungs, heart and brain were observed by the process of HematoxylinEosin staining. The Thomson Weil formula used is:

$\log m=\log D+d(f+1)$

LD50 range $==\operatorname{antilog}(\log \mathrm{m} \pm 2 \times \delta \log \mathrm{m})$

Where, $\mathrm{m}$ is the LD50 value, $\mathrm{D}$ is the smallest dose used, $\mathrm{d}$ is the log of the multiple of the dose, and $\mathrm{f}$ is the factor value from the Thomson Weil table.

\section{Statistics}

The Data were calculated by statistical software version 23 . The test carried out was two-way ANOVA $(\alpha=0.05)$ with $5 \%$ significance level.

\section{RESULTS AND DISCUSSION}

Based on Table-1, it is known that the higher the concentration of nano herbal andaliman, the higher the mortality of artemia larvae and the probit value. Based on calculations derived from the LC50 equation (Fig.-1), nano herbal andaliman have a value of $1737.80 \mathrm{ppm}$ so that this herb was one of the plants that have a mild toxic.

Table-1: LC50 Probit Value

\begin{tabular}{c|c|c|c}
\hline Treatments & Log10 & $\%$ Motality & Probit \\
\hline 10 & 1 & 0 & 0 \\
\hline 100 & 2 & 20 & 4.16 \\
\hline 1000 & 3 & 55 & 5.13 \\
\hline 10000 & 4 & 70 & 5.52 \\
\hline
\end{tabular}

\section{Dose Orientation Test}

Table-2: LD50 Dose Orientation Test

\begin{tabular}{c|c|c|c|c}
\hline Treatments & $\begin{array}{c}\text { Number } \\
\text { of mice }\end{array}$ & $\begin{array}{c}\text { Dose } \\
(\mathrm{mg} / \mathrm{KgBW})\end{array}$ & Mortality & $\begin{array}{c}\% \\
\text { Mortality }\end{array}$ \\
\hline P1 & 3 & 9 & 0 & 0 \\
\hline P2 & 3 & 18 & 0 & 0 \\
\hline
\end{tabular}


RASĀYAN J. Chem.

Vol. 13 | No. 2 |780 - 788| April - June | 2020

\section{Preliminary Test}

\begin{tabular}{c|c|c|c|c}
\hline P3 & 3 & 36 & 0 & 0 \\
\hline P4 & 3 & 72 & 1 & 20 \\
\hline
\end{tabular}

Table-3: Preliminary Test

\begin{tabular}{c|c|c|c|c}
\hline Treatments & $\begin{array}{c}\text { Number } \\
\text { of mice }\end{array}$ & $\begin{array}{c}\text { Dose } \\
(\mathrm{mg} / \mathrm{KgBW})\end{array}$ & Mortality & $\begin{array}{c}\% \\
\text { Mortality }\end{array}$ \\
\hline P1 & 5 & 45 & 0 & 0 \\
\hline P2 & 5 & 90 & 0 & 0 \\
\hline P3 & 5 & 180 & 1 & 20 \\
\hline P4 & 5 & 360 & 3 & 60 \\
\hline
\end{tabular}

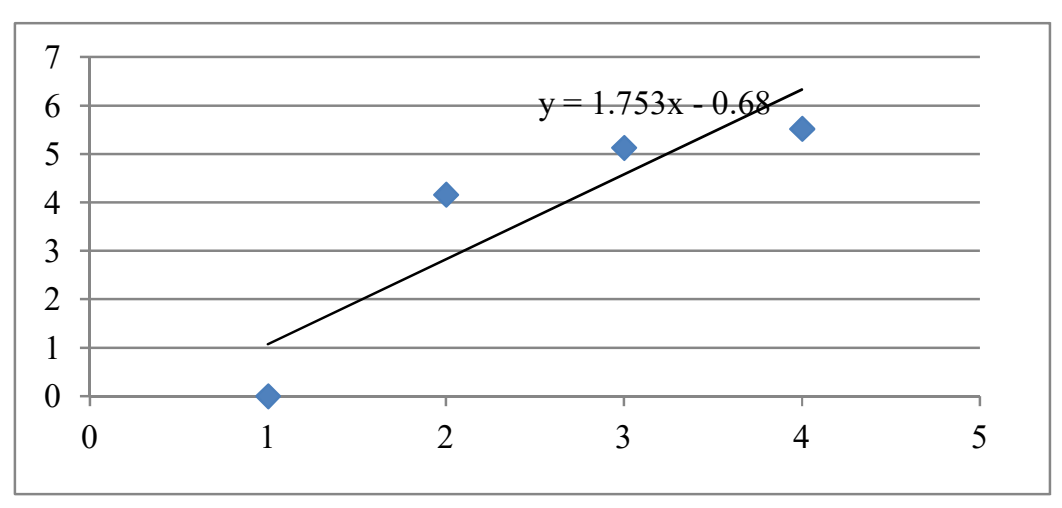

\section{LD50 Determination}

Fig-1: Graph of the LC50 Value Equation

The dose orientation stage (Table-2) used a single dosage test orally by selecting a random dose with 4 dose ranks, Death occurred in a group in observations 24 hours later carried out to the second stage. The second/preliminary test (Table-3) used 20 mice (5 mice/groups), if a death in the lowest dose of such as $180 \mathrm{mg} / \mathrm{KgBW}$ for 24 hours. The dose for the third stage (LD50 determination) used a pre-death dose which was $90 \mathrm{mg} / \mathrm{KgBW}$. Determination of dose in step 3 (Table- 4) used multiples of R dose. ${ }^{17}$ Based on the calculation of LD50 using the Thomson Weil formula, LD50 value of the nano herbal andaliman was $9.807 \mathrm{~g} / \mathrm{KgBW} \pm 0.075$. So the nano-herbal andaliman belong to the mild toxic category. Andaliman (small size) is not difficult to penetrate the body's lipid membrane. ${ }^{3,4}$ Andaliman in nanosize would carry optimal important content in cells bypassing several obstacles such as gastric acid $\mathrm{pH}$, liver metabolism and increasing circulation of drugs into the blood due small size. ${ }^{1,18 .}$

Table-4: LD50 determination

\begin{tabular}{c|c|c|c|c}
\hline Treatments & $\begin{array}{c}\text { Number } \\
\text { of mice }\end{array}$ & $\begin{array}{c}\text { Dose } \\
(\mathrm{mg} / \mathrm{KgBW})\end{array}$ & Mortality & $\begin{array}{c}\% \\
\text { Mortality }\end{array}$ \\
\hline P1 & 5 & 90 & 0 & 0 \\
\hline P2 & 5 & 127.27 & 2 & 40 \\
\hline P3 & 5 & 179.99 & 2 & 40 \\
\hline P4 & 5 & 254.55 & 3 & 60 \\
\hline P5 & 5 & 359.98 & 4 & 80 \\
\hline
\end{tabular}

\section{Organs Weight}

Giving nano andaliman herbal was influential on liver weight and a significant in liver weight $(\mathrm{p}<0.05)$ (Table-5). The liver was the largest organ in the body and very sensitive when there were toxic substances, chemicals or harmful substances entering the body. The liver acted as a detoxification organ in the body. When the nano herbal andaliman entered the body of the mice, the liver responds quickly. Changed in liver weight occur in each treatment. There was no significant difference (Table-5) on the weight of the lungs, heart and brain ( $p>0.05$ ). It was suspected because the organ did not affect or interfere with the content/compounds contained in nano herbal andaliman. 
RASĀYAN $J$. Chem.

Vol. 13 | No. 2 |780 - 788| April - June | 2020

Table-5: Weight of Organs

\begin{tabular}{l|l|l|l|c}
\hline \multirow{2}{*}{ Tretments } & \multicolumn{4}{|c}{ Organs } \\
\cline { 2 - 5 } & \multicolumn{1}{|c}{ Liver } & \multicolumn{1}{|c}{ Lungs } & \multicolumn{1}{c}{ Hearts } & Brain \\
\hline Control & $1.47 \pm 0.01^{\mathrm{a}}$ & $0.31 \pm 0.02^{\mathrm{a}}$ & $0.18 \pm 0.01^{\mathrm{a}}$ & $0.34 \pm 0.01^{\mathrm{a}}$ \\
\hline P1 & $1.50 \pm 0.04^{\mathrm{ab}}$ & $0.31 \pm 0.01^{\mathrm{a}}$ & $0.18 \pm 0.01^{\mathrm{a}}$ & $0.35 \pm 0.03^{\mathrm{a}}$ \\
\hline P2 & $1.48 \pm 0.03^{\mathrm{ab}}$ & $0.34 \pm 0.02^{\mathrm{a}}$ & $0.17 \pm 0.01^{\mathrm{a}}$ & $0.36 \pm 0.02^{\mathrm{a}}$ \\
\hline P3 & $1.57 \pm 0.08^{\mathrm{bc}}$ & $0.30 \pm 0.01^{\mathrm{a}}$ & $0.17 \pm 0.02^{\mathrm{a}}$ & $0.35 \pm 0.02^{\mathrm{a}}$ \\
\hline P4 & $1.58 \pm 0.09^{\mathrm{c}}$ & $0.34 \pm 0.03^{\mathrm{a}}$ & $0.18 \pm 0.01^{\mathrm{a}}$ & $0.33 \pm 0.03^{\mathrm{a}}$ \\
\hline P5 & $1.71 \pm 0.06^{\mathrm{d}}$ & $0.32 \pm 0.06^{\mathrm{a}}$ & $0.18 \pm 0.01^{\mathrm{a}}$ & $0.34 \pm 0.01^{\mathrm{a}}$ \\
\hline
\end{tabular}

\section{Histology of the Liver After Administration of Nano Herbal Andaliman}

There were significant differences $(\mathrm{p}<0.05)$ in normal hepatocyte cells, parenchymatic degeneration, hydrophic degeneration and necrosis (Table-6). Normal hepatocyte cell values in P1 and P2 have almost the same average. The highest parenchymal degeneration in the P1 dose, while hydrophic degeneration in P3. Giving herbal andaliman nano to mice at different doses causes damage to hepatocyte cells. The average liver damage in P1 and P2 doses was almost the same but there were significant differences ( $\mathrm{p}$ $<0.05)$ at each dose level.

Table-6: Aerage of Damages Degree in Liver

\begin{tabular}{c|c|c|c|c}
\hline Treatments & Normal & $\begin{array}{c}\text { Parenchymatous } \\
\text { Degeneration }\end{array}$ & $\begin{array}{c}\text { Hydropic } \\
\text { Degeneration }\end{array}$ & Necrosis \\
\hline Control & $53.4 \pm 2.41^{\mathrm{e}}$ & $62.4 \pm 3.28^{\mathrm{c}}$ & $25.2 \pm 6.91^{\mathrm{a}}$ & $28.0 \pm 6.42^{\mathrm{a}}$ \\
\hline P1 & $42.2 \pm 1.30^{\mathrm{d}}$ & $71.6 \pm 5.17^{\mathrm{d}}$ & $34.8 \pm 4.03^{\mathrm{ab}}$ & $41.6 \pm 5.36^{\mathrm{b}}$ \\
\hline P2 & $42.1 \pm 4.09^{\mathrm{d}}$ & $67.6 \pm 6.14^{\mathrm{cd}}$ & $39.6 \pm 6.15^{\mathrm{b}}$ & $46.4 \pm 2.19^{\mathrm{b}}$ \\
\hline P3 & $30.4 \pm 4.09^{\mathrm{c}}$ & $64.0 \pm 5.15^{\mathrm{c}}$ & $70.8 \pm 11.13^{\mathrm{d}}$ & $56.0 \pm 6.91^{\mathrm{c}}$ \\
\hline P4 & $16.0 \pm 2.55^{\mathrm{a}}$ & $52.0 \pm 5.47^{\mathrm{b}}$ & $53.4 \pm 11.69^{\mathrm{c}}$ & $160.8 \pm 4.38^{\mathrm{d}}$ \\
\hline P5 & $20.6 \pm 1.14^{\mathrm{b}}$ & $32.8 \pm 5.40^{\mathrm{a}}$ & $34.2 \pm 7.52^{\mathrm{ab}}$ & $206.4 \pm 10.04^{\mathrm{e}}$ \\
\hline
\end{tabular}

Based on observations of liver cell histology (Fig.-2) showed that the control group the most hepatocyte cells were still normal and blood vessels were still visible. In P1 dose, liver damage with parenchymous degeneration was seen more than hydrophic degeneration and necrosis. P2 also had a large but not as much parenchymous degeneration in P1. P3 had the most hydrophic degeneration than other doses and the shape of the hepatocyte cells of the liver is increasingly irregular and the density between cells decreases. This dose showed the onset of an increase in severe damage to liver cells. Cell necrosis was clear and numerous. P5 was the highest dose in this study. It appears that the damage was getting worse. The relationship between cells had a short distance and very toxic. Many cell nuclei emerge from hepatocyte cells in the liver.The Dead cell of nuclei appeared smaller, chromatin and reticular fibers multiply. Increased hepatocyte damage by chemical compounds in andaliman fruit. A study also proved that hepato protectors are widely known to protect the liver from damage. ${ }^{19}$ However, herbal liver protection was preferred by the public. Terpenoid compounds can be used as insecticides and highly toxic to animals. ${ }^{20}$ The damage would cause an immune response, and directly affect cell biochemistry. The occurrence of liver cell necrosis could be identified by changes in the cytoplasm and cell nucleus. ${ }^{21}$

\section{Histology of the Lungs After Administration of Nano Herbal Andaliman}

Based on Table -7, the control group had thick membranes and complete alveoli cells. Blood vessels in the control group were also clearly visible and the distance between the alveoli was not far. P1 began to decrease in thickness on the membrane, and the shape of the lumen did not bind completely. P3 had an irregular lumen, reduced membrane thickness and an alveolar relationship between the dense. P4 had an alveolar membrane that was not thick and the relationship between the alveoli away. P5 was the highest dose and a break in the relationship between the alveoli and the irregular shape of the lumens (Fig-3). The relationship between alveoli in the pulmonary organ in the control group showed that the extracellular matrix consists of intact collagen and elastin fibers. Alveolar lumen looked different and damage to the structure of the lung microanatomy caused by damage to epithelial and endothelial cells in the alveoli. Physiologically, free radicals or incoming toxic substances were detoxified by macrophages, neutrophils, 
RASĀYAN J. Chem.

Vol. 13 | No. 2 |780 - 788| April - June | 2020

and eosinophils. However, an excessive increase in the airway would trigger the movement of macrophages, neutrophils, and eosinophils which can cause an inflammatory reaction that could lead to more cell damage and death. ${ }^{22,23}$ The pathologically changed cause narrowing of the airways and airway obstruction. ${ }^{24}$ Therefore excessive doses will cause respiratory problems in mice.

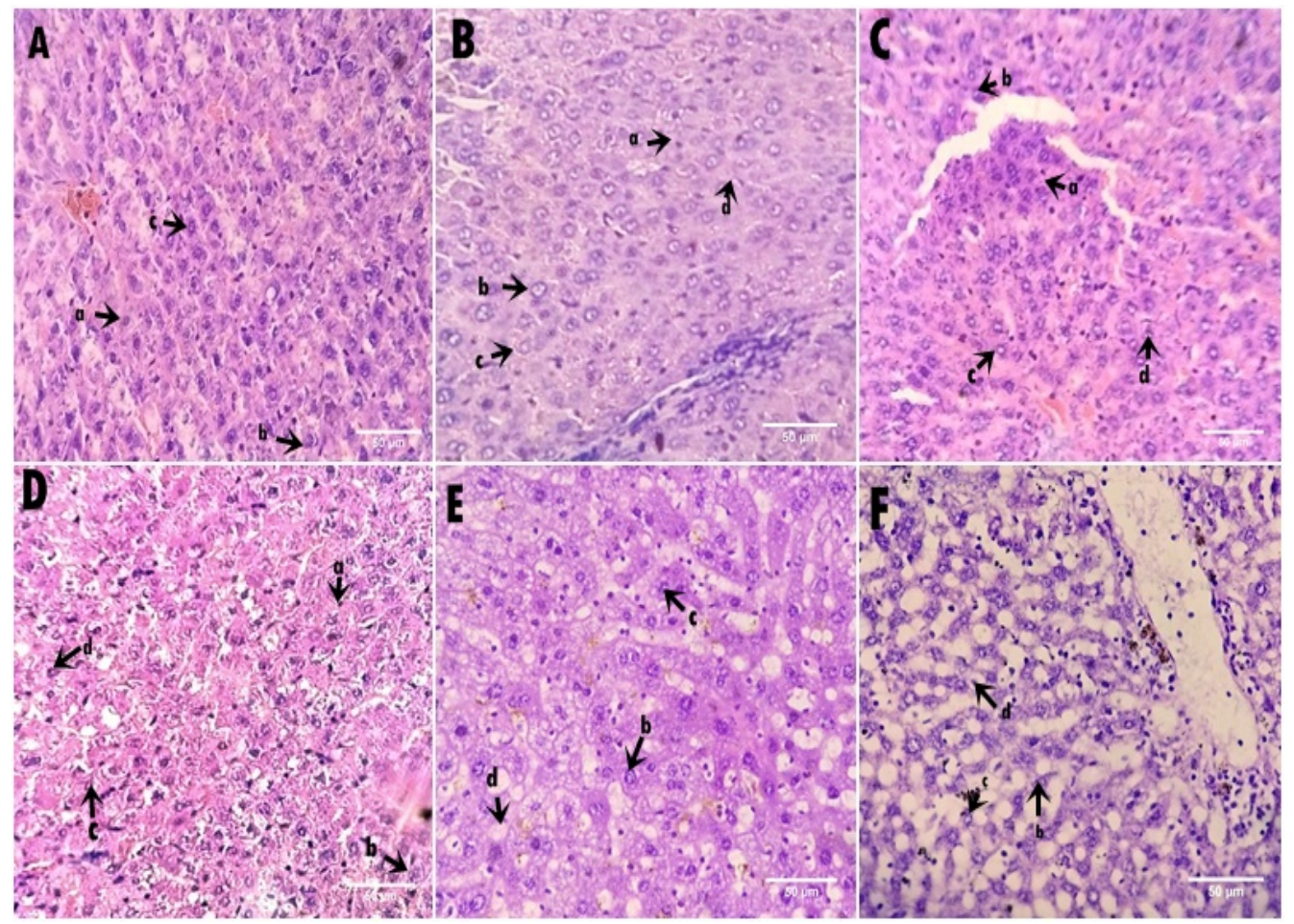

Fig.-2: Histolgy of Liver Damages. (A.)Control, (B.)P1(90mg/KgBW), (C.) P2 (127.27mg/KgBW), (D.)P3 (179.99mg/KgBW), (E.) P4(254.55mg/KgBW), (F.)P5(359.98mg/KgBW).

a. Normal hepatocytes, b. Parenchymatous hepatocytes, c. Hydropic hepatocytes, d. Necrosis cell (40x)

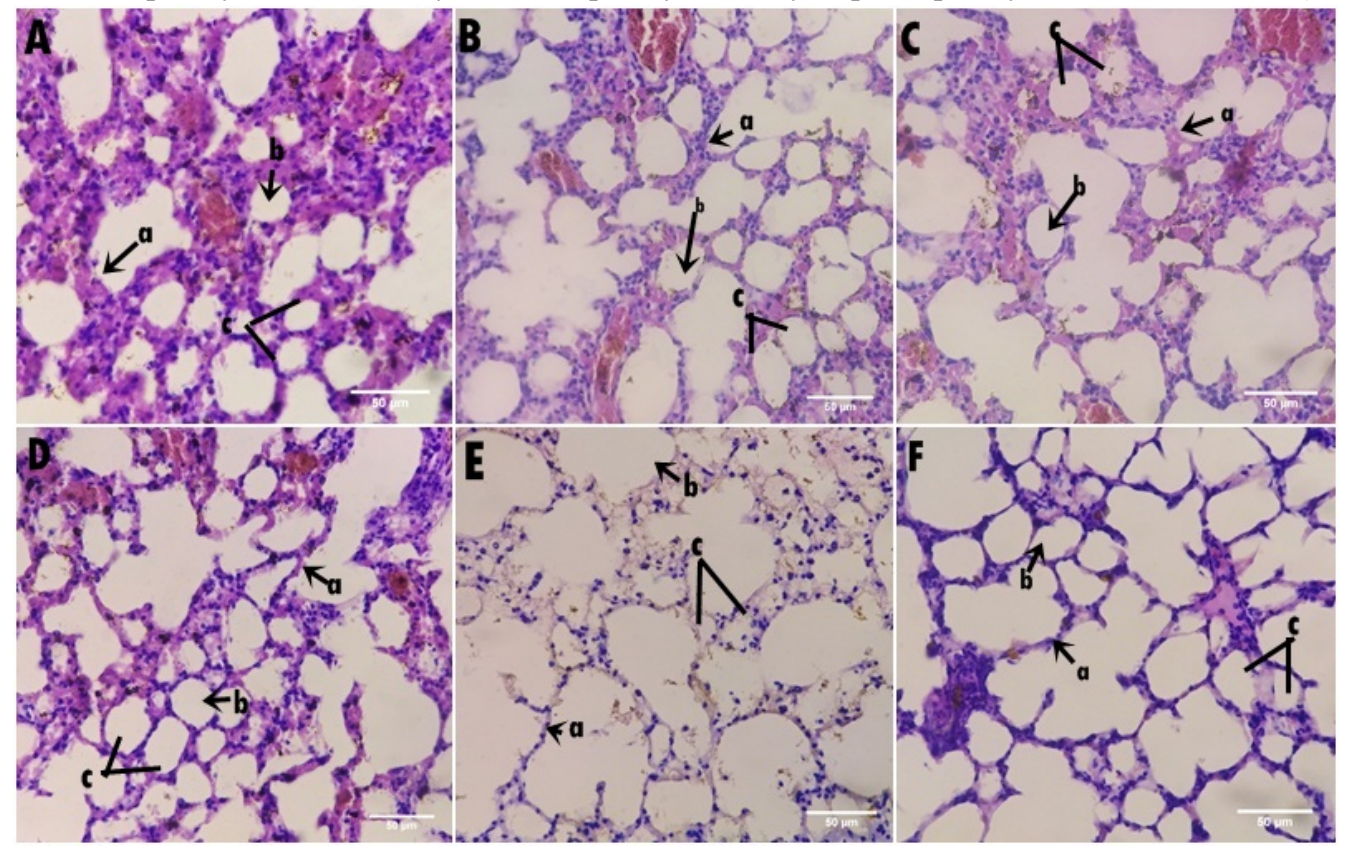

Fig.-3:Histology of Lungs. (A.)Control, (B.) P1(90mg/KgBW), (C.)P2 (127.27mg/KgBW), (D.)P3 (179.99mg/KgBW), (E.) P4(254.55mg/KgBW), (F.)P5(359.98mg/KgBW).

a. Alveolar Membrane Thickness, b. Lumen Alveolus, c. Relationship between alveoli (40x) 784 
RASĀYAN J. Chem.

Vol. 13 | No. 2 |780 - 788| April - June | 2020

Table-7: Average of Damages Degree in Alveolus Lungs

\begin{tabular}{l|l|l|l}
\hline Treatments & $\begin{array}{c}\text { Alveolar } \\
\text { Membrane } \\
\text { Thickness }\end{array}$ & $\begin{array}{c}\text { Lumen } \\
\text { Alveolus }\end{array}$ & $\begin{array}{c}\text { Relationship } \\
\text { between alveoli }\end{array}$ \\
\hline Control & $1.44 \pm 0.17^{\mathrm{a}}$ & $2.04 \pm 0.08^{\mathrm{a}}$ & $1.32 \pm 0.18^{\mathrm{a}}$ \\
\hline P1 & $1.48 \pm 0.33^{\mathrm{a}}$ & $2.00 \pm 0.14^{\mathrm{a}}$ & $1.84 \pm 0.41^{\mathrm{b}}$ \\
\hline P2 & $1.68 \pm 0.30^{\mathrm{a}}$ & $2.16 \pm 0.17^{\mathrm{ab}}$ & $2.16 \pm 0.17^{\mathrm{c}}$ \\
\hline P3 & $1.72 \pm 0.54^{\mathrm{a}}$ & $2.16 \pm 0.33^{\mathrm{ab}}$ & $2.2 \pm 0.14^{\mathrm{c}}$ \\
\hline P4 & $2.52 \pm 0.22^{\mathrm{b}}$ & $2.36 \pm 0.09^{\mathrm{b}}$ & $2.36 \pm 0.17^{\mathrm{cd}}$ \\
\hline P5 & $2.72 \pm 0.11^{\mathrm{b}}$ & $2.64 \pm 0.29^{\mathrm{c}}$ & $2.64 \pm 0.26^{\mathrm{d}}$ \\
\hline
\end{tabular}

\section{Histology of the Hearts After Administration of Nano Herbal Andaliman}

Heart damage affected the heart muscle cells after administration of nano herbal andaliman (Table-8). They had damage with varying degrees of damage at each dose level. There was a significant difference $(\mathrm{p}<0.05)$ in normal heart muscle cells, parenchymous degeneration and necrosis but no significant difference in hepatocytes of the liver that changed hydrophically $(p>0.05)$. Normal muscle cell values in P1, P2 and P3 (the same average). The highest parenchymal degeneration was P3 dose, while hydrophic degeneration and necrosis in P5. Histology of cardiac cells (Fig.-4) showed that at each dose level parenchymalosa degeneration, hydrophic degeneration, necrosis, cardiac muscle cells form increasingly irregular and reduced density between cells. Parenchymal degeneration was reversible, and cells could return to their original state. However, in severe or persistent stress and irreversible injuries occur. The heart muscle is a target for autoimmune inflammation. Old age, thymoma, and anti-CV1 antibodies appear to be risk factors that can lead to recognizing cardiac involvement. ${ }^{25,26}$ The activity of this plant with the appropriate dosage, can be used as an antioxidant by inhibiting the formation of oxygen free radicals (ROS) which can damage cancer cells. ${ }^{27}$

Table-8: Average of Damages Degree in Hearts

\begin{tabular}{l|l|l|l|c}
\hline Treatments & Normal & $\begin{array}{c}\text { Parenchymatous } \\
\text { Degeneration }\end{array}$ & $\begin{array}{c}\text { Hydropic } \\
\text { Degeneration }\end{array}$ & Necrosis \\
\hline Control & $62.8 \pm 0.83^{\mathrm{e}}$ & $43.2 \pm 5.40^{\mathrm{a}}$ & $19.2 \pm 3.42^{\mathrm{a}}$ & $18.4 \pm 9.20^{\mathrm{a}}$ \\
\hline P1 & $64.8 \pm 0.84^{\mathrm{d}}$ & $46.8 \pm 6.09^{\mathrm{b}}$ & $19.9 \pm 3.46^{\mathrm{a}}$ & $21.6 \pm 9.22^{\mathrm{a}}$ \\
\hline P2 & $62.6 \pm 2.80^{\mathrm{d}}$ & $43.6 \pm 7.40^{\mathrm{bc}}$ & $22.8 \pm 6.22^{\mathrm{a}}$ & $25.6 \pm 9.21^{\mathrm{a}}$ \\
\hline P3 & $57.4 \pm 2.88^{\mathrm{c}}$ & $54.4 \pm 4.35^{\mathrm{bc}}$ & $22.2 \pm 5.84^{\mathrm{a}}$ & $32.0 \pm 10.21^{\mathrm{a}}$ \\
\hline P4 & $47.2 \pm 6.57^{\mathrm{b}}$ & $52.4 \pm 2.19^{\mathrm{bc}}$ & $19.2 \pm 6.55^{\mathrm{a}}$ & $80.8 \pm 11.01^{\mathrm{b}}$ \\
\hline P5 & $40.6 \pm 3.13^{\mathrm{a}}$ & $51.6 \pm 3.84^{\mathrm{c}}$ & $28 . .2 \pm 4.52^{\mathrm{a}}$ & $96.8 \pm 11.04^{\mathrm{b}}$ \\
\hline
\end{tabular}

Histology of the Brain After Administration of Nano Herbal Andaliman

In the cerebellum, there are purkinje cells that play an important role in controlling movement. Nanoherbal andaliman affected the number of purkinje cells in the brain of mice. There was a significant difference $(p<0.05)$. However, this number was inversely related to brain cell necrosis in mice. Necrotic heart cells were lowest in the control group and highest in the P5 group. The higher the dose of nano herbal andaliman, the higher the necrosis of mouse cells in the brain. Based on statistical tests there was a significant difference $(\mathrm{p}<0.05)$ in necrosis of brain cells in mice after administration of nano herbal andaliman in each dose level. Based on observations of brain cell histology (Fig.-5) showed the control group had many purkinje cells. Purkinje cells in P3 and P4 decreased the relationship between cells away and necrosis was increasing. P5 had very much cell necrosis and long-distance of the relationship between cells. This dose could interfere with the central nervous system in mice. The cerebellum and hippocampus are the parts of the brain that are most vulnerable to damage by oxidative stress because they have low antioxidant activity. ${ }^{28}$ Some researchers claimed that oxidative stress could induce the formation of free radicals that cause cell damage and death. ${ }^{29,30}$ The higher the andaliman dose, the lower the number of cells in the rat brain. Research using andaliman using ethanol extract also showed a significant reduction in the number of Purkinje cerebellum cells. ${ }^{31-34}$ Nano-herbal andaliman research also plays a role in preeclampsia. $^{35}$ This research concludes that testing for acute toxicity from solid dispersions is very important to be evaluated because it ensures safety and effectiveness of the formulation. ${ }^{36}$ 
RASĀYAN J. Chem.

Vol. 13 | No. 2 |780 - 788| April - June | 2020

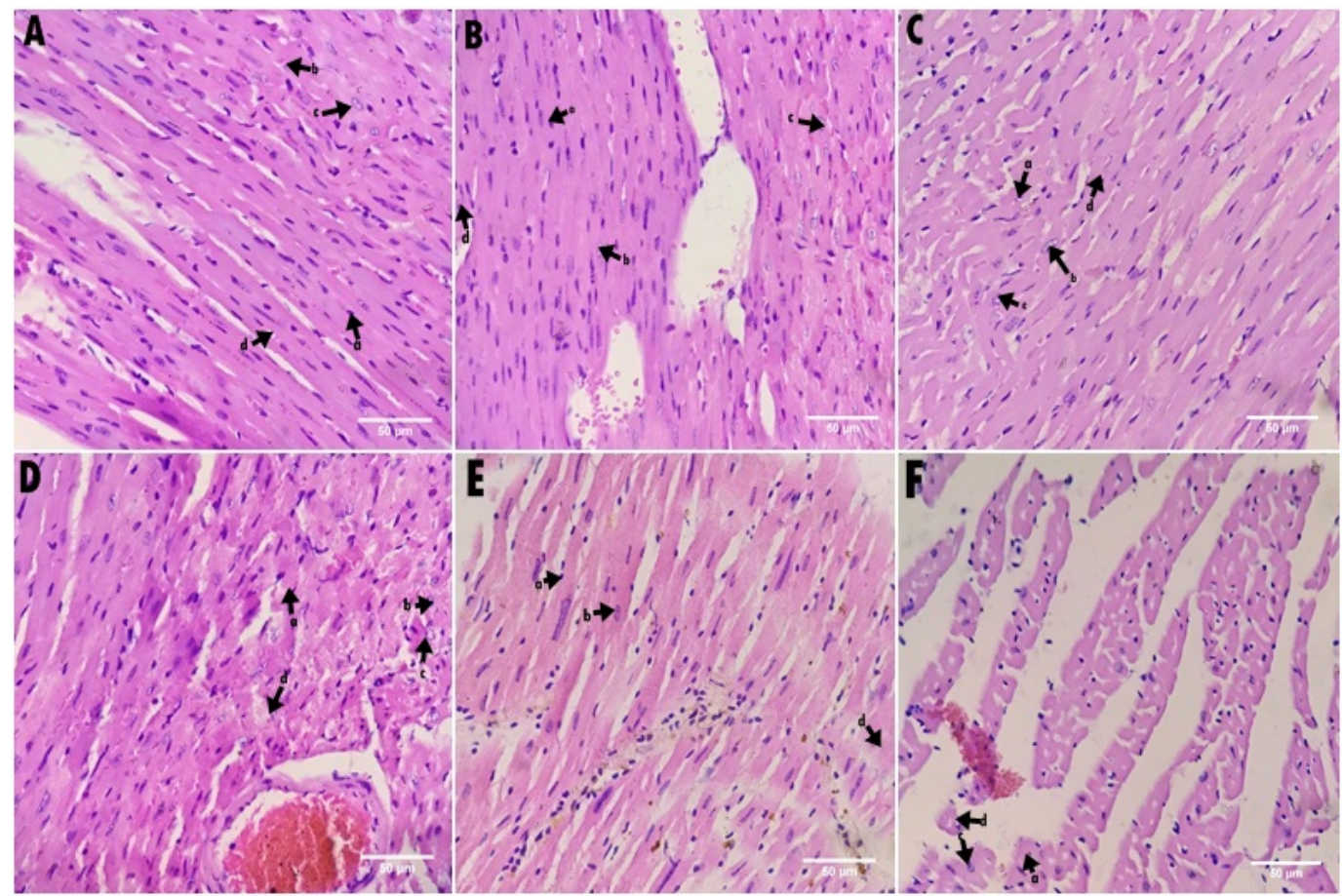

Fig.-4: Histology of Heart Damages (A.)Control, (B.)P1(90mg/KgBW), (C.)P2 (127.27mg/KgBW), (D.)P3 (179.99mg/KgBW), (E.) P4(254.55mg/KgBW), (F.)P5(359.98mg/KgBW).

a. Normal of heart cells b. Parenchymatous cells, c. Hydropic cells, d. Necrosis cell (40x)

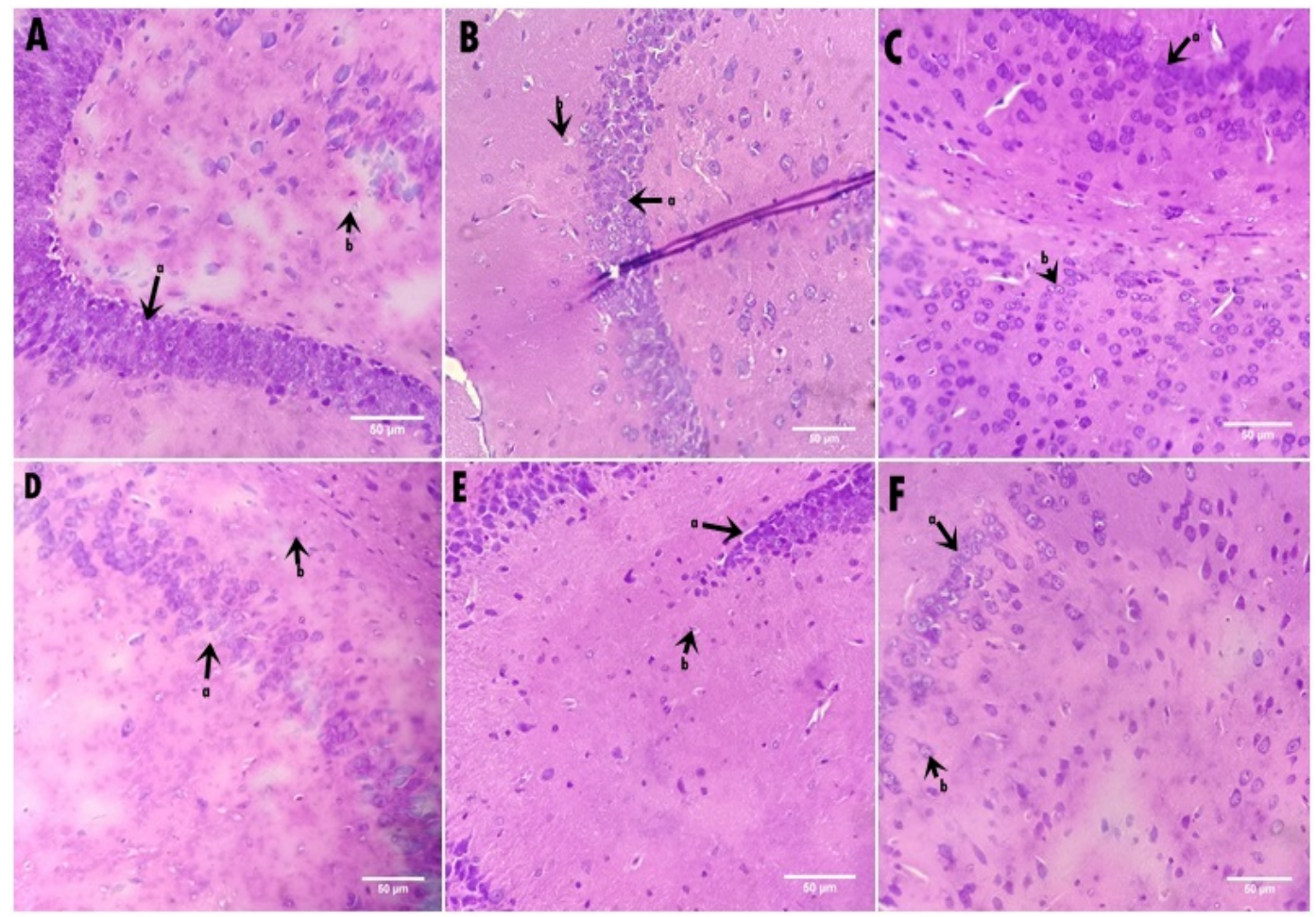

Fig.-5: Histology of Necrosis Cells in Brains, (A.)Control, (B.) P1(90mg/KgBW), (C.)P2 (127.27mg/KgBW), (D.)P3 (179.99mg/KgBW), (E.) P4(254.55mg/KgBW), (F.)P5(359.98mg/KgBW). a. Purkinje cells, b. Necrosic cell (40x). 
RASĀYAN J. Chem.

Vol. 13 | No. 2 |780 - 788| April - June | 2020

\section{CONCLUSION}

LC50 value of $1737.80 \mathrm{ppm}$ and LD50 of $9.807 \mathrm{~g} / \mathrm{KgBW} \pm 0.075$ after given nano herbal andaliman, so that this plant in nanosize is classified as a mild toxic category and a significant difference $(p<0.05)$ at each dose level against the histological in the liver, lungs, heart and brain.

\section{ACKNOWLEDGMENT}

We thank the Ministry of Research, Technology and Higher Education for funding our research in the second year PMDSU Grant (Number: 11/E1/KP.PTNBH/2019).

\section{REFERENCES}

1. S.H. Anshari, F.Islam and M. Sameem, Journal of Advanced Pharmaceutical Technology \& Research, 3(3),(2012), DOI:10.4103/2231-4040.101006

2. R. K. Thapa, M. K. Gulam, P. B. Kalpana, T. Parbati, Asian Journal of Biomedical and Pharmaceutical Sciences, 3(24),12(2013).

3. K.T. Dewandari, S.Yasni, S.Yuliani, Jurnal Pascapanen, 10(2),58 (2013).

4. S. Saraf and Ajazuddin, Fitoterapia, 81(7), 688(2010), DOI:10.1016/j.fitote.2010.05.001

5. C.H. Wijaya, I.T. Hadiprodjo, A. Apriyantono, Jurnal Teknologi Industri Pangan, 12(2), 117(2012).

6. A. Parhusip, S. Yasni, Y. Elisabeth, Jurnal Ilmu Teknologi Pangan, 1(1),112(2003).

7. E. Suryanto, H. Sastrohamidjojo, S. Raharjo, Tranggono, Indonesian Food and Nutrition Progress, 11(2),48(2004), DOI: https://doi.org/10.22146/jifnp.38

8. T. Guo, X. F. Tang. J. Chang, Y. Wang, Natural Product Research, 31(1),16(2017), DOI: $10.1080 / 14786419.2016 .1205064$

9. T. Guo, L.P. Dai, X.F. Tang, T.T. Song, Y. Wang, A. Zhaou et al. Natural Product Research, 31(20),2335(2017), DOI:10.1080/14786419.2017.1303695

10. M. Tiwary, S. N. Naik, D. Tewari, P. K. Mittal, S. Saraf, Journal of Vector Borne Diseases, 44(3), 198 (2007).

11. G. J. Amabeoku, C.G. Kinyua, International Journal of Pharmacology, 6(6),844(2010), DOI: 10.3923/ijp.2010.844.853

12. T. Guu, Y.X. Deng, H. Xie, C.Y. Yao, C.C. Cai, S.L. Pan, et al, Fitoterapia. 82(3),347(2011), DOI: $10.1016 /$ j.fitote.2010.11.004

13. J. K. Sahni, S. Baboota, J. Ali, Pharmacy Times, 43,16(2011).

14. S. H. Ansari,F. Islam, and M, Sameem, Journal of Advanced Pharmaceutical Technology \& Research, 18(3),142(2012), DOI: 10.4103/2231-4040.101006

15. P.C.Situmorang and S. Ilyas, Asian Journal of Pharmaceutical and Clinical Research,11(11), 462(2018), DOI:10.22159/ajpcr.2018.v11i11.29042

16. H. Lucida, Y. Primadini, Suhatri, Rasayan Journal of Chemistry,12(2),728(2019), DOI: 10.31788/RJC.2019.1224068

17. BPOM RI. Pedoman Uji Toksisitas Non Klinik Secara In Vivo, Jakarta,(2014).

18. N. K. Bairwa, N. K. Sethiya, S. H. Mishra, Pharmacognosy Research, 2(1), 26(2010), DOI: $10.4103 / 0974-8490.60584$

19. B. Cahyono, J. Ariani, H. Failasufa, M. Suzery, S. Susanti and H. Hadiyanto, Rasayan Journal of Chemistry, 12(1),7(2019), DOI:10.31788/RJC.2018.1144076

20. N. Kaplowitz. Seminars in Liver Disease,22(2), 137(2002), DOI:10.1055/s-2002-30100

21. J.G. Evans and W.H. Butler. Histopathology in Safty Evaluation. Experimental Toxicology. The Basic Issues. 2nd edition. D. Anderson and D.M. Conning (eds). Hartnolls Ltd, Bodmin (1993).

22. R.G. Schnellmann, R.S. Goldstein, Toxic Responses of Kidney, In Klaassen CD, editor Casarett and doull's Toxicology the Basic Science of Poisons, New York: The McGraw-Hill (2001).

23. S. L. Robbins, V.Kumar, Buku Ajar Patologi II, 4th ed., Jakarta: EGC (1995).

24. M. Gutowski and S. Kowalczyk, Acta Biochimica Polonica, 60(1),11(2013), DOI:10.18388/abp.2013_1944

25. M. Silva and P. Bercik, Laboratory Investigation. 92(6),937 (2012), DOI:10.1038/labinvest.2012.15

26. F.Romi, Autoimmune Diseases,1-5 (2011), DOI:10.4061/2011/474512 
RASĀYAN J. Chem.

Vol. 13 | No. 2 |780 - 788| April - June | 2020

27. H. Ding, Y.W. Chin, A.D, Kinghorn and S.M, D’Ambrosio, Seminars in Cancer Biology, 17(5), 386, (2007), DOI:10.1016/j.semcancer.2007.04.003

28. G.I. Henderson, J.J.Chen, S. Schenker, Frontiers in Bioscience, 4, D541 (1999).

29. M.B. Heaton, J.J. Mitchell, M. Paiva, Alcoholism: Clinical and Experimental Research, 24 (4), 512(2000).

30. S.E. Maier and J.R West, Alcohol, 23 (1), 49(2001).

31. J.D. Thomas, C.R. Goodlett, J.R. West, Developmental Brain Research,105 (2),159(1998).

32. T. Miki, S. Harris, P. Wilce, Y. Takeuchi, K.S. Bedi, Journal of Anatomy, 194(3),423(1999), DOI: 10.1046/j.1469-7580.1999.19430423.x

33. W.J. Chen, S.E. Parnell, J.R. West, Alcohol, 15(1), 34, (1998).

34. S.Ilyas, S. Hutahaean, Nursal, International Journal of PharmTech Research, 9, 444, (2016)

35. P.C. Situmorang, S. Ilyas, S.Hutahaean and Rosidah, Pharmaceutical Sciences, 25(3),205(2019), DOI:10.15171/PS.2019.37

36. B.V.Udugadeand S. P. Gawade, Rasayan Journal of Chemistry, 11(1),118(2018), DOI: 10.7324/RJC.2018.1111860.

[RJC-5621/2019] 